\title{
KASVATUS\&AIKA
}

AJankohtaista

https://doi.org/10.33350/ka.110975

\section{Sata vuotta oppivelvollisuutta}

\author{
Jukka Rantala
}

Tänä vuonna oppivelvollisuus täytti sata vuotta. Suomen kasvatuksen ja koulutuksen historian seura huomioi juhlavuoden järjestämällä oppivelvollisuuden kehitystä tarkastelleen seminaarin ja julkaisemalla vuosikirjansa Koulu ja menneisyys - Oppivelvollisuus 100 vuotta. Tässä tekstissä tarkastelen näiden innoittamana oppivelvollisuuskoululle asetettuja tavoitteita sekä yhtäältä niiden muuttumista ja toisaalta muuttumattomuutta. Teksti nostaa esille oppivelvollisuuskoulussa sadan vuoden aikana tapahtuneet rakenteelliset muutokset ja perustelee oppivelvollisuuden laajentamista toiselle asteelle.

Opi rakastamaan ensin yhtä lasta, niin opit rakastamaan kaikkia muita! Opi uskomaan, että lapsi yleensä koettaa tehdä työtä niin paljon kuin hän pienillä voimillaan voi! Olen varma siitä, että silloin koulussasi aina paistaa kirkas, herttainen päivä. (Merikoski 1922, 95.)

Näin ohjasi opettaja seuraajaansa oppivelvollisuuslain tultua voimaan. Lainaus kertoo sata vuotta sitten toimineen koulun hengestä ja tavoitteista. Lapselle ei asetettu tiedollisesti kovia tavoitteita osittain siksi, että lapset tulivat kouluun hyvin erilaisista lähtökohdista. Opettajien oli myös voitettava lasten huoltajien hyväksyntä koulunkäynnille etenkin maaseudulla, jossa lasten työnteko nähtiin välttämättömyytenä ja koulunkäynti toissijaisena. Osalle vanhemmista olisi riittänyt se, että heidän lapsensa oppivat lukemaan ja kirjoittamaan. Jotkut pelkäsivät koulunkäynnin kasvattavan lapsistaan työtä vieroksuvia herroja.

Seuraajaansa opastaneen opettajan koulu oli maaseudun kansakoulu, jollaisia valtaosa tuon ajan kouluista oli. Elokuun ensimmäisenä päivänä vuonna 1921 voimaan astunut oppivelvollisuuslaki pakotti kunnat perustamaan kansakouluja ja velvoitti vanhempia panemaan lapsensa kouluun, joskaan oppivelvollisuuden suorittamista ei sidottu koulunkäyntipakkoon. Oppivelvollisuuslaki tarkoitti muutosta erityisesti maalaislasten elämään. Kaupungeissa lähes kaikki lapset olivat kansakouluissa tai oppikouluun johtavissa valmistavissa kouluissa. Ennen oppivelvollisuutta noin viidennes kouluikäisistä lapsista ei käynyt koulua lainkaan. Alueelliset erot koulunkäynnissä olivat kuitenkin suuret. Maaseudulla, esimerkiksi Oulun läänissä, kansakoulua kävi harvempi kuin joka kolmas kouluikäinen (Telemäki 1979, 139).

Oppivelvollisuuskoulu oli sosiaalistamisen väline. Lasten kasvatusvastuuta siirrettiin kodeilta valtiolle. Keskusta-liberaaliset poliitikot Mikael Soininen etunenässä katsoivat yhteisen koulun toimivan kansallisen eheytymisen välineenä. Hiljattain päättynyt sisällissota oli osoittanut, mihin kansan kahtiajakautuminen pahimmillaan johtaa. Jotkut tulkitsivat sodan johtuneen siitä, että rahvasta oli johdettu harhaan (Arola 2003, 141; Autio 1986, 41). 
Kansan sivistystasoa piti kohottaa ja nuoriso kasvattaa koko kansalle yhteisissä kouluissa yhdenmukaisten normien ja ihanteiden mukaisesti. Oppivelvollisuuslaki ja kaksi vuotta myöhemmin annettu laki kansakoulutoimen järjestysmuodon perusteista määrittivät kansalaisten tarvitseman perussivistyksen laajuuden.

Yleisen oppivelvollisuuden kannattajat odottivat oppivelvollisuuden tasoittavan yhteiskunnallisia eroja (Ahonen 2003, 99). Oppivelvollisuuslain toteuttaminen sujui kuitenkin hitaasti, sillä kunnat hakivat lykkäystä lain toteuttamiseen. Kansakoulun sijasta monissa kunnissa oli kiertokouluja sekä supistettuja kouluja, joiden lukuvuosi ja oppimäärä poikkesivat täydellisestä kansakoulusta. Vielä vuonna 1936 noin viisi prosenttia maaseudun kouluikäisistä lapsista laiminlöi oppivelvollisuuden suorittamisen (Rahikainen 2011, 371). Maaseudulla lasten poissaoloihin kouluista ei suhtauduttu tiukasti, vaan varsinkin sadonkorjuuaikana lasten poissaolot saatettiin katsoa pakon sanelemiksi. Oppivelvollisuuskoulu erotti kuitenkin lapsuuden selkeästi aikuisuudesta eroavaksi vaiheeksi. Oppiminen määriteltiin lasten työksi. (Tuomaala 2004, 11, 110.)

Oppivelvollisuuskoulu oli aluksi kuusivuotinen. Oppivelvollisuuden oli määrä päättyä lapsen täyttäessä 13 vuotta. Jos hän ei muulla tavoin jatkanut opintoja, hänen piti kahden vuoden ajan osallistua kansakoulun jatko-opetukseen. Toisen maailmansodan jälkeen oppivelvollisuutta pidennettiin vuodella. 1950-luvun loppupuolella tuli lisäksi kaksivuotinen kansalaiskoulu niille, jotka eivät hakeutuneet jatko-opintoihin. Yhtenäiseen yhdeksänvuotiseen peruskouluun siirryttiin 1970-luvulla. Peruskoulun myötä Suomi muuttui koulutusyhteiskunnaksi (Rahikainen 2011, 372).

Oppivelvollisuuskoulun historia näyttäytyy yhtäläistyvien koulutusmahdollisuuksien lisääntymisen historiana. Kolikon kääntöpuolena voi kuitenkin nähdä kouluttautumisen pakon (Jauhiainen 2011, 111).

Elinkeinorakenteen muutoksen seurauksena koulutetut nuoret löysivät työtä ja heidän elintasonsa kohosi vanhempiensa elintasoa korkeammalle. Koulutuksen myötä tullut lupaus paremmasta elämästä kantoi 2000-luvulle saakka. Mitä lähemmäs tätä päivää on tultu, sitä tärkeämmäksi nuorille on tullut peruskoulun jälkeinen koulutus. Koulutus ei enää tänä päivänä ole lupaus paremmasta, jos asiaa tarkastelee suhteessa edellisten sukupolvien urakehitykseen tai ansiotasoon. Koulutuksesta on yhä enemmän tullut välttämättömyys, jottei yksilö sulje itseltään tulevaisuuden mahdollisuuksia. Jo vuoden 1907 oppivelvollisuuskomitean sanat koulutuksen tärkeydestä varoittivat kouluttamattomuuden vaaroista:

Se kansan jäsen, joka jääpi sitä sivistystä vaille, jonka enemmistö itselleen hankkii, jääpi vastustamattomasti yhteiskunnan alhaisemmille portaille, eikä hänen ole useinkaan mahdollista myöhemmillä ponnistuksilla päästä muiden tasalle kohoamaan. (Oppivelvollisuuskomitean mietintö 1907, 4-5.)

Aloitin viittaamalla sata vuotta sitten eläköityneen opettajan seuraajalleen jättämään perintöön. Tänä päivänä moinen ohjeistus ei enää riitä, ei vaikka kuinka haluaisimme. Oppilas ei löydä paikkaansa jatko-opinnoista tai työelämästä, mikäli opettaja suostuu siihen, että oppilas tekee vain sen, mihin kokee kykenevänsä. Kuitenkin kuten Perusopetuksen laatukriteereissä vuodelta 2010 todetaan, "[s]uomalaisen peruskoulun kehittämisen näkökulmasta ei ole perusteltua kiinnittää huomiota pelkästään oppimistuloksiin vaan myös niihin koulun toimintoihin, jotka edistävät ja mahdollistavat tavoiteltujen oppimistulosten saavuttamisen" (Opetusministeriö 2010, 10). Edelleen sata vuotta oppivelvollisuuslain voimaantulon jälkeen koulun henkilökunnan tehtävä on huolehtia oppilaista ja tarjota heille mahdollisimman hyvät eväät tulevaisuuden rakentamiseen riippumatta oppilaiden taustoista. 
Muutosta ei ole tapahtunut myöskään niissä perusteluissa, joita on liitetty oppivelvollisuuskoulun tärkeyteen. Selviytymistä kansainvälisessä kilpailussa on sadan vuoden ajan käytetty perusteena oppivelvollisuuskoululle ja sen kehittämisen tarpeelle. Myös kuntien erilainen taloudellinen tilanne on sadan vuoden ajan näkynyt oppivelvollisten opiskeluaikojen eroina. Siinä missä täydellisen kansakoulun käyneen opiskeluaika saattoi olla kaksinkertainen supistetussa kansakoulussa opiskelevaan verrattuna, voi peruskoululainen tänä päivänä asuinkunnasta riippuen saada yhdeksän vuoden aikana puolen kouluvuoden verran toista peruskoululaista enemmän opetusta (Halila 1950, 89-92; Kahila \& Hämäläinen 2017; Pitkänen ym. 2017).

Oppivelvollisuuskoulussa on kuitenkin paljon muuttunut sadassa vuodessa. Oppivelvollisuuskoulun alkutaipaleella koulu kasvatti poikia työntekijäkansalaisuuteen mutta tyttöjä äitiyteen (Tuomaala 2004). Kansakoulun vaalimien kansalaisihanteiden sukupuolittuneisuus pysyi tiukassa. Koulu myös ohjasi tietynlaiseen kansalaisuuteen, mitä kaikki koululaiset ja heidän perheensä eivät hyväksyneet. Tämän päivän oppivelvollisuuskoulu sen sijaan pyrkii antamaan kaikille yhtäläiset mahdollisuudet riippumatta oppilaan sukupuolesta tai taustasta.

\section{Lähteet}

Oppivelvollisuuskomitean mietintö 1907. Komiteanmietintö 1907:12a.

\section{Kirjallisuus}

Ahonen, Sirkka 2003. Yhteinen koulu. Tasa-arvoa vai tasapäisyyttä. Tampere: Vastapaino. Arola, Pauli 2003. Tavoitteena kunnon kansalainen. Koulun kansalaiskasvatuksen päämäärät eduskunnan keskusteluissa 1917-1924. Helsingin yliopiston kasvatustieteen laitos.

Autio, Veli-Matti 1986. Opetusministeriön historia IV. Ensimmäisen tasavallan kulttuuripolitiikka 1917-1944. Helsinki: Opetusministeriö.

Halila, Aimo 1950. Suomen kansakoululaitoksen historia III. Oppivelvollisuuskoulun alkuvaiheet (1921-1939). Porvoo: WSOY.

Jauhiainen, Annukka 2011. Työläis- ja maalaisnuorison pidentyvä koulutie. Teoksessa Heikkinen, Anja \& Leino-Kaukiainen, Pirkko (toim.), Valistus ja koulun penkki. Kasvatus ja koulutus Suomessa 1860-luvulta 1960-luvulle. Helsinki: Suomalaisen Kirjallisuuden Seura, 111-119.

Kahila, Mari \& Hämäläinen, Veli-Pekka 2017. Asuinpaikka ratkaisee: lapsi voi saada peruskoulun aikana puoli vuotta enemmän opetusta kuin toinen. Yle uutiset 17.11.2018 [www-lähde]. < https://yle.fi/uutiset/3-9933827 > (Luettu 18.8.2021).

Merikoski, K. 1922. Vanhan opettajan muistelmia. Helsinki: Kotikasvatusyhdistys.

Opetusministeriö 2010. Perusopetuksen laatukriteerit. Opetusministeriön julkaisuja 2010:6. Helsinki: Opetusministeriö.

Pitkänen, Kari, Hievanen, Raisa, Kirjavainen, Tanja, Suortamo, Markku \& Lepola, Laura 2017. Valtiontalouden säästöjen vaikutukset sivistyksellisiin oikeuksiin. Helsinki: Kansallinen koulutuksen arviointikeskus.

Rahikainen, Marjatta 2011. Kansakoulun vuosisata 1866-1966 tilastojen valossa. Teoksessa Heikkinen, Anja \& Leino-Kaukiainen, Pirkko (toim.), Valistus ja koulun penkki. Kasvatus ja koulutus Suomessa 1860-luvulta 1960-luvulle. Helsinki: Suomalaisen Kirjallisuuden Seura, 370-379. 
Telemäki, Matti 1979. Tampereen kansakoulun historia 1872-1976. Tampereen kaupunki.

Tuomaala, Saara 2004. Työtätekevistä käsistä puhtaiksi ja kirjoittaviksi. Suomalaisen oppivelvollisuuskoulun ja maalaislasten kohtaaminen 1921-1939. Helsinki: Suomen Historiallinen Seura.

Jukka Rantala on historiallis-yhteiskuntatiedollisen kasvatuksen professori Helsingin yliopistossa. 